\title{
A “Lived-In Model" to Teacher Education: The Impact of Embedding Pre-Service Teacher Education on Secondary Student Learning
}

\author{
Brad M. Maguth, Alfred W. Daviso \\ The University of Akron, Akron, Ohio, USA \\ Email: bmaguth@uakron.edu
}

How to cite this paper: Maguth, B. M., \& Daviso, A. W. (2018). A "Lived-In Model" to Teacher Education: The Impact of Embedding Pre-Service Teacher Education on Secondary Student Learning. Creative Education, 9, 1504-1524.

https://doi.org/10.4236/ce.2018.910111

Received: June 5, 2018

Accepted: August 4, 2018

Published: August 7, 2018

Copyright (c) 2018 by authors and Scientific Research Publishing Inc. This work is licensed under the Creative Commons Attribution International License (CC BY 4.0).

http://creativecommons.org/licenses/by/4.0/

\begin{abstract}
This study undertook a five-month quantitative investigation into the ways in which a "lived-in" model to teacher education supported the learning of thirty-nine 10th grade students. For over sixteen weeks, forty-six teacher candidates across two subject areas (Social Studies and Language Arts) mentored, tutored, and taught two periods of 10th grade high school students. Under the supervision of their methods professor and a cooperating teacher, teacher candidates planned and implemented rigorous and individualized instructional units. In order to better understand any relationship between 10th graders receiving treatment under this model $(\mathrm{n}=39)$ and their academic performance, all 10th grade students $(n=236)$ were surveyed three times throughout the semester. Furthermore, the beginning and end of semester GPA of all 10th grade students were monitored. Findings include 10th graders participating in the "lived-in model" demonstrating statistically significant gains in attitudes toward school and improved academic progress when compared with those 10th graders not participating. Implications of these findings are discussed in relation to teacher preparation programs partnering with area schools to better meet the needs of both teacher candidates and secondary students.
\end{abstract}

\section{Keywords}

Clinical Experience, Field Experience, Partnerships, Teacher Preparation, Teacher Education

\section{Introduction}

As high school teachers and as university instructors, we have witnessed and 
even been complicit in teacher preparation programs being a part of the problem rather than the solution in helping PK-12 educators and administrators meet the needs of learners. This involves instructors and university field placement officers engaging in a mad rush to place teacher candidates in random classrooms to "clock" as many field hours as possible. Teachers and students in urban schools are often overwhelmed with requests by universities to place their teacher candidates in short, limited, and unsupervised field experiences (Darling-Hammond, 2010).

Teacher candidates, mostly made-up of white university students that are not from urban communities, often buy into the stereotypes and misinformation surrounding urban youth, mostly students of color (Sleeter, 2008; Gay, 2000). In an attempt to get a mostly white and suburban pre-service teacher pool acclimated to multicultural schools and neighborhoods, there have been teacher preparation programs that have implemented urban field experiences that are often poorly planned and supported; which tend to reinforce stereotypes and amount to "spectacles" where teacher candidates get to "view the exotic" then travel back home to their comfortable confines of the suburbs while padding their resumes.

The placement of pre-service teachers in many PK-12 schools results in teacher preparation programs using limited resources that often go undercompensated and/or unreimbursed, and at times unappreciated. Pre-service teachers frequently enter their field experience bearing large checklists of tasks they need to perform (i.e. interview students and teachers, review classroom textbooks, collect copies of syllabi and assignments, etc.), given to them by their professors-most of whom have never met with classroom teachers in advance (Zeichner, 2012; Zeichner, 2010). Little regard is given to the extra-time and effort it takes teachers to organize these tasks and mentor candidates-all in an age of mounting demands placed on teachers like high-stakes testing and accountability measures (Kopkowkis, 2008).

Teachers, especially, those working with our most vulnerable PK-12 students, should not be fatigued and worse-off for having volunteered to help their local universities prepare the next wave of educators. Nor should PK-12 teachers have to jeopardize the learning of their students in order to advance the preparation of pre-service teachers. Instead of having to choose between their own students' learning and the preparation of pre-service teachers, we believe university-based teacher preparation programs can engage in mutually beneficial partnerships that both advance PK-12 student learning while preparing the next wave of skilled and competent teachers our society desperately needs. Knowing that a transformation away from outdated and ineffective field placements and towards university-school partnerships was needed, we set out to design and study a "lived-in" model to teacher preparation.

Intensive clinical education, which benefits all involved community partners, has been a foundational element in the medical professions. Through well-supervised opportunities for university students to gain and apply learnings 
in real medical settings with patients and families, research shows candidates are better prepared for success (Fairbrother, Nicole, Blackford, Nagarajan, \& McAllister, 2016). This approach is emerging in teacher education as requirements for accreditation include intensive clinical experiences (CAEP, 2013). Campus Mentors is one such approach that includes a win-win partnership between a local education agency and a university to assist at-risk youth (Washburn-Moses, 2014). A multi-year study found the program to be mutually beneficial and effective in helping to prepare pre-service teachers for success in the teaching profession, while also helping to improve the academic and social outcomes of elementary, middle, and high school students (Washburn-Moses, 2014). The Community Teaching Strand involved a similar approach where a local school district, its broad community members, and an area university partnered to promote community-based learning within teacher preparation. In this model, pre-service teachers were assigned to a local school, then, given well-supervised and intensive clinical experiences in order to gain valuable local community knowledge as to best meet the unique learning needs of its students. However the program only lasted a few years (Zeichner, Bowman, Guillen, \& Napolitan, 2016). Guillen \& Zeichner (2018) found that more research is needed on how to both build and sustain these win-win partnerships between local schools and pre-service teacher preparation programs.

It is all too common to hear university students and in-service teachers criticize teacher preparation faculty and their programs for living in their ivory towers, and being out of touch with the needs of teachers in today's classrooms (Giles \& Moore, 2006). The lack of sustained and meaningful experience in schools working with students and teachers leads educators to consistently criticize teacher preparation programs as being "too theoretical" and neglecting to provide pre-service teachers with frequent and supportive PK-12 classroom experiences, tools, and strategies that improve educator practice and PK-12 student learning. Thus, more than three in five education school alumni report that their teacher preparation program did not prepare them for "classroom realities" (U.S. Department of Education, 2011). It was Sir William Osler (1901) that noted, "He who studies medicine without books sails an uncharted sea, but he who studies medicine without patients does not go to sea at all." This lack of commitment to teaching as a profession of practice fosters a gap between how teachers are trained and what schools actually need (NCATE, 2010). In order to grow as an educator, teachers-well before student teaching/their culminating clinical experience-must be provided with sustained and supportive opportunities in schools that allow for meaningful interactions with PK-12 students, teachers, administrators, and even university faculty. The growing emphasis on educational philosophies and understanding education research becomes highly theoretical and undervalued without pre-service teachers having actual, concrete experiences with PK-12 students to draw from in their teacher preparation experience.

The leading national accreditor of teacher education programs, the Council 
for the Accreditation of Educator Preparation (CAEP), notes that “...to prepare for the unprecedented responsibilities educators are required to take on, the U.S. must dramatically transform teacher preparation (NCATE, 2010)." This transformation must entail teacher preparation programs and their faculty prioritizing and investing in initiatives that allow teacher candidates the opportunity to learn and train alongside university faculty in schools. This call for "learning about practice in practice" (Ball \& Cohen, 1999) and for closer collaboration between PK-12 schools and university teacher preparation program isn't new and reaches back to the early 20th Century with calls by the National Association of Directors of Supervised Student Teaching, now the Association of Teacher Educators (Patterson, McGoech, \& Olson, 1990). In fact, it was John Dewey (1904/1965) that noted the promise of grounding teacher education in practice and the lives of learners. Several decades of research makes it clear that critical elements of professional teacher practice can only be learned in real classrooms under guidance from faculty mentors (Zeichner \& Bier, 2015; Ball \& Cohen, 1999; Hollins, 2015).

Evolving out of the notion that subject-specific methods courses and their adjoining field placements, which usually come before student teaching/the 16 week practicum experience, could do more to get methods students in supportive, sustained, and mutually beneficial field placements (Kenyon, 2013; Passe 1994), and in turn could afford a rigorous, relevant, and differentiated curriculum to PK-12 students, Brad Maguth (Author 1) worked to locate models of teacher preparation that promoted strong collaboration and partnerships between schools and university teacher preparation programs. It was essential for this model to allow university methods professors to deliver on-site instruction and coaching to methods students, and to facilitate clear communication and interaction with cooperating teachers. This model also needed to embed teacher education in actual classrooms whereby university methods candidates plan, instruct, assess, and reflect with their methods professor for a sustained period of time in a real classroom, with real students. Finally, it was essential that this model advanced and put at its center PK-12 student learning.

\section{In Practice: A Lived in Model to Teacher Preparation}

Knowing that subject specific methods courses are at the core of advancing essential pedagogical content knowledge, it is essential for pre-service candidates enrolled in methods courses to engage in supportive, relevant, authentic, and rewarding field experience in real classrooms (Kenyon, 2013; Adler, 2008; Henning \& Yendol-Hoppey, 2004; Toll, Nierstheimer, Lenski, \& Kolloff, 2004; Passe, 1994). Subject specific field experiences attached to and/or embedded in methods courses can play a significant role in laying an important foundation of pedagogical content knowledge before students move into full-time student teaching (Doppen, 2007). Research in social studies education indicates that when methods professors place students in random social studies classrooms 
candidates often experience instructional approaches and beliefs that run contrary to what they learned in social studies methods courses (Toll et al., 2004). As a result, university method learnings were "washed clean" or discredited by pre-service teachers as they advanced in their program. In order to avoid this washout and to better connect theory and best-practice, it was essential the methods professor spend significant time on-site delivering instruction, the professor have a direct, supportive, and trusting relationship with the cooperating teacher, and that methods students and faculty be embedded for sustained periods of time in the PK-12 classroom (Zeichner \& Bier, 2015; Kenyon, 2013; Passe, 1994). For all of these reasons, a "lived-in" model for teacher preparation was implemented in the spring of 2012 in Maguth's social studies methods course.

The authors had learned about this cost-free model to teacher preparation and its ability to reach those most vulnerable students through Foster \& Nosol's (2008). America's Unseen Kids: Teaching English Language Arts in Today's Forgotten High Schools. In this book, Foster \& Nosol discuss a lived-in model to teacher preparation that was highly successful in advancing a rigorous and differentiated English Language Arts secondary curriculum to some of this nation's most vulnerable high school students in Akron, Ohio. In this model, Foster \& Nosol identify the benefits of moving teacher preparation programs and methods courses into PK-12 schools. This includes leveraging necessary resources to support the extra-ordinary efforts of teachers in helping help our nation's most vulnerable and often invisible students succeed. Foster \& Nosol (2008) assert this model not only benefits PK-12 students, teachers, and administrators but provides an authentic and meaningful laboratory in which university faculty can work alongside teacher candidates in their teacher preparation. Zeichner \& Bier (2015) reviewed research on university-based teacher preparation programs that situated teacher education in schools, and moved instruction into schools where faculty work side by side with practicing teachers to prepare candidates. While research on these initiatives is scarce, Zeichner \& Bier (2015) describe how urban teacher residency programs and certain methods and foundation courses at the University of Wisconsin have found success embedded teacher preparation in local public schools.

Drawing from numerous discussions with Hal Foster, as he's a colleague of the authors at a midsized Midwestern university, and using his book as a resource, Maguth decided to embed his twenty-three social studies methods students in one 10th Grade U.S. History class at an urban high school. Under this model, all teacher candidates enrolled in social studies methods ( 3 credit hours) and its co-requite field experience ( 2 credit hours) were required to be on-site at an area urban high school Monday through Friday from 12:50 pm until 3 pm. This requirement was similar to the requirement Hal Foster had for his Secondary Language Arts methods students. Since Hal Foster's lived-in model was highly valued by administrators at one local, large urban high school Maguth 
was invited by the Principal of this same school to meet with the Social Studies Department Chair in order to pitch the idea of expanding the lived-in model into social studies. Fortunately, the Department Chair agreed and allowed Maguth and his students to start teaching his 6th and 7th block 10th grade U.S. History courses in the spring of 2012. Sixth block was a U.S. History course that met on Mondays and Wednesdays between 12:50-2:30, and on Fridays between 12:50 and 1:37. 7th block was another U.S. History course that met on Tuesdays and Thursdays between 12:50 and 2:30, and from 1:40 to 2:30 on Fridays. This timeframe worked well as it provided the methods students and Maguth the opportunity to debrief on their teaching with the cooperating teacher at the end of the day, between 2:30 - 3 pm Monday through Friday. For an overview of how class is arranged Monday through Thursday see Table 1.

Under this lived-in model, 10th grade teachers worked alongside university methods professors on-site in order to promote collaboration and sustain communication. On-site methods students researched and planned units of instruction for implementation in two periods (6th Block and 7th Block) in their teacher's classroom and in dedicated classroom space for the university methods students. In the first three weeks, methods students became acclimated to the school, built a strong rapport with high school students, were issued copies of the curriculum (i.e. exams, content standards, texts, etc.) and began the process of planning rigorous and relevant units which were vetted by their methods professor and the 10th grade teacher. In weeks four through sixteen, pre-service teachers took over all instructional responsibilities from the 10th grade U.S. teacher for both blocks to implement their approved units. All units included an advanced curriculum that prioritized individualized instruction, small/well supervised group activities, and project-based learning. For more information on how this new lived-in model compared to the previously implemented traditional model at this university see Table 2 .

All 10th graders at this urban school are teamed, meaning that all 10th grade students on a team travel together from teacher-to-teacher. 10th grade teachers are afforded common planning time, and since they have the same students they are well positioned to reach across subject areas to discuss student performance and to plan and implement interdisciplinary units. The university methods

Table 1. An overview of the class schedule and student engagement.

\begin{tabular}{|c|c|}
\hline Class time & Student Engagement \\
\hline $12: 30-12: 50$ & University Classroom (briefing on today's lesson) \\
\hline $12: 50-1: 40$ & $10^{\text {th }}$ Grade U.S. History Class or English Language Arts \\
\hline $1: 40-1: 45$ & $\begin{array}{l}\text { University Classroom While } 10^{\text {th }} \text { Graders on a } 5 \text { Minute Break (briefing on } \\
\text { lesson, and what to expect } 2^{\text {nd }} \text { half of class) }\end{array}$ \\
\hline $1: 45-2: 30$ & $10^{\text {th }}$ Grade U.S. History Class or English Language Arts \\
\hline $2: 30-3: 00$ & $\begin{array}{l}\text { University Classroom (debriefing on the lesson with the entire class and } 10^{\text {th }} \\
\text { grade teacher, and overview of what to expect next class) }\end{array}$ \\
\hline
\end{tabular}


Table 2. Lived-in model compared to traditional model.

\begin{tabular}{|c|c|c|}
\hline & $\begin{array}{l}\text { Traditional Model For Secondary } \\
\text { Methods Courses }\end{array}$ & $\begin{array}{l}\text { Lived-in Model For Secondary Methods } \\
\text { Courses }\end{array}$ \\
\hline Location & On campus & High school classroom \\
\hline Days/Time & $\begin{array}{l}\text { Monday \& Wednesday } \\
\text { 1:00 - 3:00 pm }\end{array}$ & $\begin{array}{l}\text { Monday - Friday } \\
12: 50-3: 00 \mathrm{pm}\end{array}$ \\
\hline 50 Field Hours & $\begin{array}{l}\text { Completed based upon the students } \\
\text { availability }\end{array}$ & Completed at the high school \\
\hline $\begin{array}{c}\text { Program } \\
\text { Characteristics }\end{array}$ & $\begin{array}{l}\text { 1) Assigned to one of five random } \\
\text { area schools across } 17 \text { different } \\
\text { teachers (no teacher acclimation). } \\
\text { 2) Little supervision ( } 1 \text { - } 3 \\
\text { observations per semester) per } \\
\text { student. } \\
\text { 3) Little on-site course instruction, as } \\
\text { most communication was done via } \\
\text { email. } \\
\text { 4) Candidates were asked to complete } \\
\text { a checklist (i.e. observation notes, } \\
\text { textbook analysis, etc.), and co-teach } \\
\text { a minimum of one lesson plan. }\end{array}$ & $\begin{array}{l}\text { 1) All candidates assigned to one school } \\
\text { with one } 10^{\text {th }} \text { grade secondary teacher. } \\
\text { 2) By week four, the candidates take full } \\
\text { instructional responsibility for blocks } 6 \& \text { } \\
7 \text {. } \\
\text { 3) Candidates put in groups of } 2 \text { - } 3 \text { to } \\
\text { plan and implement units. Must be } \\
\text { approved by methods class, methods } \\
\text { instructor, and cooperating teacher before } \\
\text { implementation. Class reviews and } \\
\text { provides feedback on group units. } \\
\text { 4) On-site instruction by professor and } \\
\text { cooperating teacher. } \\
\text { 5) Candidates expected to build strong } \\
\text { rapport with students, and teach every } \\
\text { day. }\end{array}$ \\
\hline
\end{tabular}

professor and teacher candidates attend 10th grade team meetings when possible. In the past, social studies methods students and their professor have teamed with English Language Arts university methods students and their professor (who have also engaged in this lived-in model) to plan and implement 10th grade interdisciplinary units (in Global Education and STEM) at the high school. At the beginning of the semester, methods students become familiar with the primary goals and principals of the lived-in model.

These include:

1) Focusing on developing "strong" high school students (providing an advanced and meaningful curriculum, pushing/motivating students, etc.);

2) Engaging in long-term, sustained relationships with high school students (rapport building, making the invisible student visible, fostering individualized instruction, strengthening teacher-student relationship, etc.);

3) Reflecting on the quality of instruction provided to high school students and adjusting the project where/when necessary to meet the needs of 10th graders.

Throughout the semester university method students work with their peers in teams to plan, construct, implement, and reflect on instruction in their discipline. In the first week, methods students were presented with the required units to be implemented, as selected in consolation with the 10th grade teacher. In the social studies, 2 - 3 students are assigned to a unit, and these two week units included such topics as the Great Depression, WWII, Cold War, and U.S. in the World Today. In English Language Arts, methods students are placed in one of three groups that developed advanced and differentiated units of study: Group 1 
(a semester long Reading Group) focuses on constructing rigorous activities that prioritize reading and interpreting complicated text, Group 2 (a semester long Writing Group) focuses on building advance writing skills whereby 10th graders are better prepared to articulate their thoughts, communicate clearly, and build strong arguments, and Group 3 (Shakespeare Group) developed and implemented a two week long unit that requires students to read, interpret, reflect on, and act out scenes of Shakespeare's work. While groups rotated in their planning and implementing units, all methods students were responsible for teaching 10th grade students in class each day. 10th graders frequently worked individually and in small groups with methods students, which allowed for differentiated and individualized instruction - all of which would be more difficult with just one teacher delivering whole class instruction. 10th graders looked forward to seeing and working with their university social studies methods students, and at times, rich trajectory changing relationships with the secondary students were forged.

After one year of implementing this lived in model to teacher preparation, Maguth frequently observed the significant impact it was having on 10th grade students-some of whom were the most academically vulnerable. While on site, it was commonplace for 10th graders in our U.S. History class to approach Maguth (the methods course professor) to tell him how a university methods student inspired them, taught them, and made a difference. The 10th grade U.S. History teacher and Maguth observed a change in both 10th graders and social studies method students' classroom performance, as this authentic learning environment enlivened classroom discussions. With so many trained, competent, and caring adults in the room, youth looked forward to coming to class and noted how they felt special with all the individual attention they received. While the antidotal information of the success of this project and partnership accumulated, Maguth decided to form a research team focused on better understanding ways in which this lived-in model to teacher education influenced the learning of the 10th graders we worked with. In order help in program evaluation and program assessment, a research team was assembled that included Maguth and Daviso.

\section{The Research Study: A Lived-In Model to Teacher Preparation}

This 2013 study undertook a five-month quantitative investigation into the ways in which a lived-in model to teacher education supported the learning of thirty-nine 10th grade students. For sixteen weeks in the fall, forty-six teacher candidates (23 secondary social studies teacher candidates and 23 English Language Arts candidates) mentored, tutored, and taught two periods of 10th grade high school students. Under the supervision of their methods professor and cooperating teacher, methods students planned and implemented rigorous and individualized instructional units. In order to better understand any relationship between 10th graders receiving treatment under this model $(n=39)$ and their 
academic performance, all 10th grade students in the school $(\mathrm{n}=236)$ were surveyed three times throughout the semester. Furthermore, the beginning and end of semester GPA of all 10th grade students was monitored. These data sources were collected in order to answer our research questions:

1) After embedding a university methods class and their adjoining field experience in an urban 10th grade U.S. History classroom and English Language Arts classroom, which allowed teacher candidates to provide on-site instruction, individualized attention, mentoring, and tutoring, how did the attitudes and perceptions towards school of 10th grade students receiving this treatment compare to those 10th graders not receiving the treatment?

2) How did those 10th grade students receiving the treatment compare with those 10th graders that did not participate in regard to overall GPA?

\subsection{Research Methods}

The authors collected data, in order to answer their research questions, from all 10th grade students at the high school-those students being taught and mentored by the university methods students; or, those, receiving the treatment, and those not receiving the treatment. In particular, the authors collected data through the administration of a Social Emotional Factors survey. This survey instrument was pre-approved by the high school and frequently administered by the local school districts starting in spring 2013 to over 2500 high school students. The decision was made by the authors to use this pre-existing instrument and its accompanying fall 2013 data to determine what, if any, the impact of our lived-in model to teacher participation had on the social emotional health and performance of the 10th graders methods students we worked with. Furthermore, we collected and analyzed data through monitoring the first and second quarter GPA of all 10th graders.

\subsection{Data Analysis}

Social Emotional Variables

Research indicates that students' social, emotional, and psychological attitudes and beliefs toward school can play a profound role in short and long term academic performance and trajectories (Yeager \& Walton, 2011). Interventions that are sustained and persuasive and focus on better understanding students' thoughts, feelings, beliefs, and self-worth can lead to large student academic gains and achievements (Blackwell, Trzesniewski, \& Dweck, 2007; Walton \& Cohen, 2007). Good, Aronson, \& Inzlicht (2003)'s field research which paired low and middle income Black and Hispanic or Latino 7th grade females with university student mentors showed the experimental group receiving the socio-emotional intervention had earned significantly higher standardized test scores than the control group. This lived-in model to teacher preparation required university method students to build strong, supportive relationships with high school students in an attempt to advance their socio-emotional health. We 
believed these strong relationships and overall rapport held the potential to improve 10th graders academic performance. Since there were 46 university methods students and 39 high school students (20 students in Period 6 and 19 in Period 7), we focused on getting to know the 10th graders individually in order to make them feel safe, encouraged, and appreciated. At its core, we believed that these rich 1:1 relationships of university students with secondary students would help make instruction personally relevant, and provide for the individualization of instruction-all leading to student success.

In order to better understand the influence of this project on 10th graders' social emotional health, in particular, their attitudes and perceptions towards school, a survey was administered three times in the fall semester of 2013 (beginning, middle, end) to all 10th grade students. It was determined that the results of this survey would be categorized into those 10th graders being mentored and taught by university methods students in 6th and 7th block (university assisted-UA/treatment group) and those 10th graders not receiving the treatment (secondary students in other blocks/control group). After this categorization, trends, themes, and discrepancies were identified across both groups.

The survey instrument employed had been administered locally previously and validated. The Appendix provides sample items and reliability values for each factor under study. The instrument was a social emotional assessment being piloted across several public school sites in one county as a means for promoting common understanding of adolescent development. In particular, this survey included items that were adapted from the Patterson of Adaptive Learning Scales (PALS) which examines the relationship between learning environment and student motivation and behavior (Midgley, Maehr, Hruda, Anderman, Anderman, Freeman, Gheen, Kaplan, Kumar, Middleton, Nelson, Roeser, \& Urdan, 2000). Midgely, Maehr, Hurda, Anderman, Freeman, Gheen, Kaplan, Middleton, Nelson, Roeser, \& Urdan (2000) research indicates particular social emotional factors have a profound impact on student perceptions, attitudes, and motivation. Drawing from these identified factors, student responses on the 36 survey items cut across two categories: Climate Perception Factors and Student Motivation Factors. Climate Perception Factors are those climate/environmental factors that influence student attitudes, perceptions, and performance at school. The Student Motivation Factors influence student identity, motivation, and achievement at school. These two categories and their subcategories, or, factors (nine total), which were used to write instrument items, are discussed more below:

Climate Perception Factors

1) Academic Press-Centered on educators challenging students and setting high expectations for performance.

2) Academic Support-Centered on educators providing students with the assistance and help they need in order to be successful in school.

3) Positive Peer-Relationships-Centered on creating a favorable classroom en- 
vironment where students are accepted amongst their peers and feel they fit in.

4) Sense of Safety-Centered on students feeling physically and psychologically safe at school.

\section{Student Motivation Factors}

1) Mastery Orientation-Centered on students' desire to understand and master course content, and their perceived value of content taught.

2) Self-Efficacy-Centered on students' belief that they can learn and succeed in class if they work hard and study.

3) College-Going Identify-Centered on students' desire to attend college/post-secondary instruction.

4) Future Self-Centered on students having a plan for what they want to do in the future following high school graduation, and they look forward to a successful future.

5) School Value-Centered on students understanding how their success in school aligns to their future goals and aspirations.

Each 10th grade homeroom teacher (8 total) received a packet that included pre-labeled surveys for their students to complete. There were 236 10th grade students enrolled, and 213 10th graders participated in all three rounds of surveys (90\% response rate). Across 6th and 7th block, the 10th grader response rate was $80 \%$ (31/39). Each survey had a student's name, class period, and corresponding teacher's name pre-printed. Pre-printed directions were provided to the teacher that they were asked to share with students before their completion of the survey. Students were directed to decide how true each statement was for them on a Likert-type scale ( $1=$ Not true at all; $6=$ Very true for me). Students completed the surveys in approximately 10 minutes. After all students completed the survey, the teacher placed them in a provided envelope, sealed them, and returned them to the researchers.

Survey responses were collected and sorted according to time, such that the first survey was administered at Time 1 (September), the second at Time 2 (late October) and the final at Time 3 (December). Individual students were matched across time periods so that only students who participated in surveys before, during and after the experiment were included in analyses. Students were coded according to group membership (e.g. UA treatment vs. control).

General Linear Modeling was used to determine the effects of university collaboration on student social emotional changes over time. Each factor from the student survey was entered as a dependent variable, with Time entered as a fixed factor and group membership entered as a random factor. Program effects were determined by analyzing the interaction effects of group membership by time. Responses for the control group and experimental group were compared across the two categories and nine factors with special attention towards trends, themes, and discrepancies.

\section{Academic Achievement Variable}

Grade point average (GPA) was used as a global assessment of student academic achievement during the experiment. Grade point averages are calculated 
on a traditional grading scale (0 - 4.0). Marking period (not cumulative) GPAs were extracted from the student information system at the end of the first quarter (early October) and second quarter (early January) of the school year. University methods students began instruction when approximately $75 \%$ of the first quarter had already passed, and it was assumed to be unassociated with student achievement during that marking period.

The dependent variable of academic achievement in the analysis was second quarter GPA. Hierarchical multiple linear regression modeling was used to study the effects of the project, after controlling for first quarter GPA. First quarter GPA was entered as an independent variable in the first block. Group membership was entered in the second block $(1=\mathrm{UA}$ treatment group; $0=$ control group). GPAs for the control group and UA treatment group were compared with special attention towards trends, themes, and discrepancies.

\section{Findings}

Based upon collected data, 10th grade students mentored, tutored, and taught by the university methods teacher candidates in English Language Arts and U.S. History-those receiving the treatment-demonstrated increased gains when compared with those 10 th graders not receiving the treatment. In particular, those 10th graders being mentored by the methods students demonstrated:

1) Stability or gains across all nine social emotional factors (across Climate Perception Variables and Student Motivation Variables). In particular, statistically significant gains in four of the nine factors (Academic Press, Adult Support, Positive Peer Relationships, and Sense of Safety) when compared with those 10th graders that did not receive the treatment.

2) Statistically significant effect of program participation on second quarter GPA, after controlling for initial GPA. Students who did not receive the treatment experienced declines in overall GPA while those students that did receive the treatment maintained or increased their overall GPA.

\section{Finding 1: Social Emotional Health}

After controlling for initial levels of the factors via a pre-experimental survey (round 1 in October), students in the experimental condition reported gains across all nine factors, with there being statistically significant outcomes in four factors: Academic press, academic support, sense of safety, and in peer connections (see Figures 1-4). This suggests that 10th grade students in the university collaboration sections (6th and 7th Block of U.S. History) experienced large gains not experienced by those 10th graders not being mentored by university methods students. There were statistically significant differences between 10th graders in the experimental and control groups on two student motivation variables at Time 1 (mastery orientation and school value), such that students in the experimental condition began with higher levels, compared with students in the control conditions. These differences remained statistically significant across the experiment (see Table 3). 


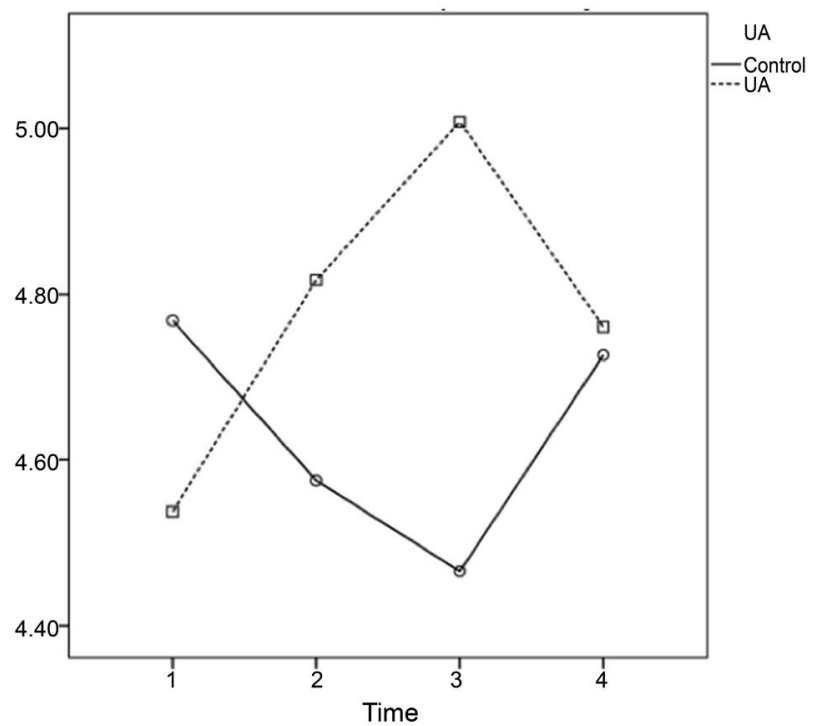

Figure 1. Academic press experienced by students.

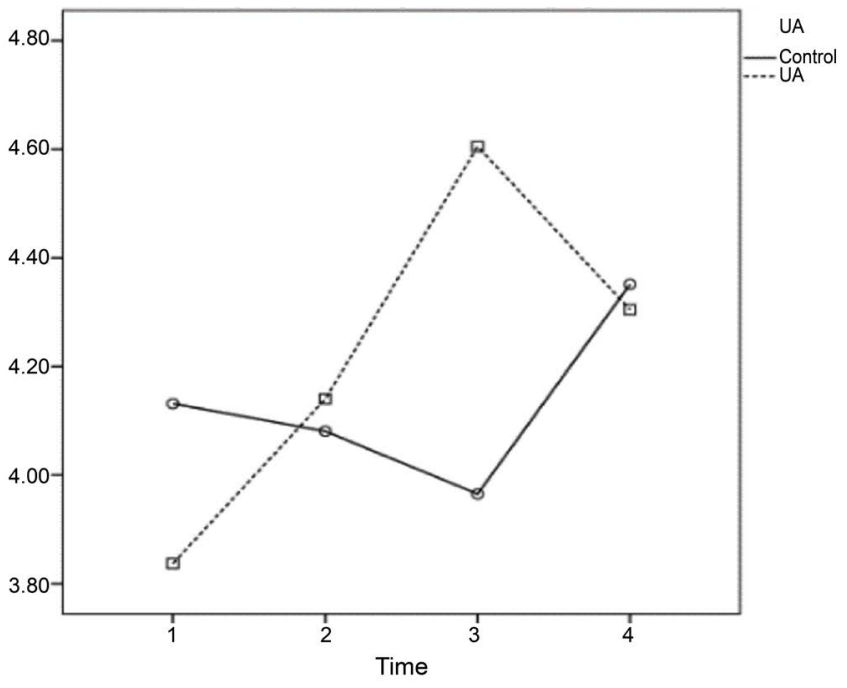

Figure 2. Sense of safety reported by students (Physical and Psychological).

Table 3. Comparison of groups at each survey administration.

\begin{tabular}{|c|c|c|c|c|c|c|c|c|c|c|}
\hline Time & Group & $\begin{array}{c}\text { Academic } \\
\text { Press }\end{array}$ & $\begin{array}{l}\text { Academic } \\
\text { Support }^{*}\end{array}$ & $\begin{array}{l}\text { Sense of } \\
\text { Safety* }\end{array}$ & $\begin{array}{c}\text { Peer } \\
\text { Connections }{ }^{*}\end{array}$ & Mastery & Self-Efficacy & $\begin{array}{l}\text { College } \\
\text { Identity }\end{array}$ & Future Self & School Value \\
\hline \multirow{2}{*}{1} & Control & 4.77 & 4.34 & 4.13 & 4.78 & 4.92 & 4.85 & 5.21 & 4.93 & 5.17 \\
\hline & UA & 4.54 & 4.16 & 3.84 & 4.57 & 4.89 & 4.73 & 5.15 & 4.83 & 5.27 \\
\hline \multirow{2}{*}{2} & Control & 4.58 & 4.35 & 4.08 & 4.55 & 4.63 & 4.72 & 5.05 & 4.99 & 4.93 \\
\hline & UA & 4.82 & 4.53 & 4.14 & 4.87 & 4.94 & 5.07 & 5.47 & 5.02 & 5.35 \\
\hline \multirow{2}{*}{3} & Control & 4.47 & 4.14 & 3.97 & 4.39 & 4.69 & 4.81 & 5.09 & 4.97 & 4.97 \\
\hline & UA & 5.01 & 4.94 & 4.60 & 4.90 & 5.04 & 5.10 & 5.35 & 5.25 & 5.37 \\
\hline \multirow{2}{*}{4} & Control & 4.73 & 4.56 & 4.34 & 4.69 & 4.82 & 4.84 & 5.13 & 4.97 & 5.07 \\
\hline & UA & 4.76 & 4.69 & 4.30 & 4.63 & 4.80 & 5.04 & 5.31 & 5.30 & 5.27 \\
\hline
\end{tabular}

*Bolded numbers represent statistically significant differences at that point in time. ${ }^{*}$ Significant interaction effect $(p<0.05)$ for these variables. 


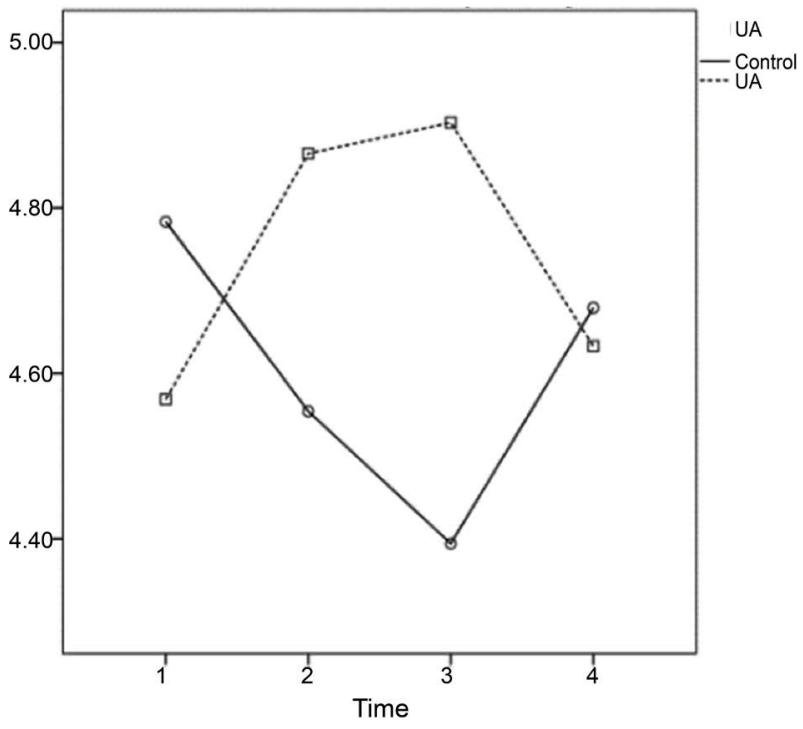

Figure 3. Peer connections reported by students.

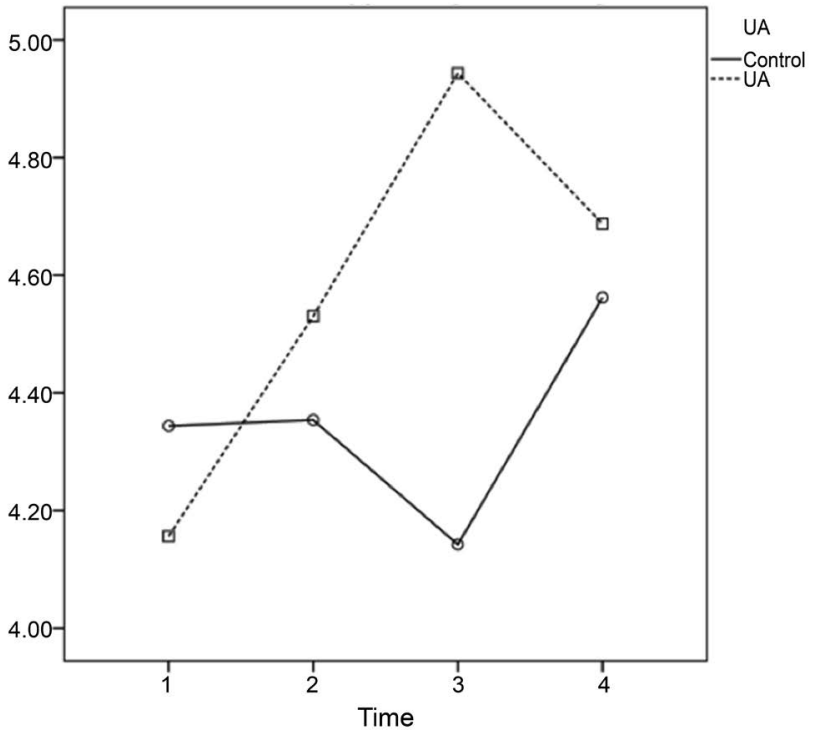

Figure 4. Academic support reported by students.

\section{Finding 2: Academic Performance}

Students in the UA treatment group maintained a consistent GPA throughout the semester. In contrast, the comparison group GPA declined on average. Results of the regression analysis indicated a statistically significant effect for first quarter GPA ( $\mathrm{B}=0.996, p<0.001)$ and also for membership in the experimental group $(\mathrm{B}=0.189, p<0.01)$. Findings indicate that students receiving the treatment were 2.5 times more likely to earn higher GPAs than the control group in the second quarter. In particular, 10th graders being mentored by the social studies methods students maintained a consistent average GPA throughout the semester, while those high school students in the control group demonstrated an average GPA decline (see Table 4). 
Table 4. Results of a Multilevel Regression Analysis to determine effects on GPA.

\begin{tabular}{cccccc}
\hline & \multicolumn{2}{c}{ Unstandardized Coefficients } & $\begin{array}{c}\text { Standardized } \\
\text { Coefficients }\end{array}$ & $\mathrm{t}$ & Sig. \\
\hline Variable & $\mathrm{B}$ & Std. Error & Beta & & \\
(Constant) & -0.228 & 0.113 & & -2.020 & 0.045 \\
GPA101 & 0.996 & 0.037 & 0.878 & 26.893 & 0.000 \\
Experimental Condition & 0.189 & 0.071 & 0.087 & 2.649 & 0.009 \\
\hline
\end{tabular}

${ }^{*}$ Effects of university collaboration condition are statistically significant $(p<0.01)$.

\section{Limitations}

While we believe these findings provide significant insights into a lived-in model to teacher preparation, we believe it's also important to report limitation of these findings. First, since both social studies and English Language Arts methods students were working with the same 10th graders (Block $6 \& 7$ ), it is hard to disaggregate which group had the greatest influence on the overall academic performance (i.e. GPA) and socio-emotional performance of secondary students. In future research, we would recommend localizing student grades and attendance in each subject area and period as core sources of data.

Second, this study was dependent upon self-reported student data when administering the social emotional survey. While this approach is a cost-effective strategy in collecting data on large samples, collected data is limited in that it is dependent upon youth understanding what each item is asking and their providing honest, accurate answers (Austin, Gibson, Deary, McGregor, \& Dent, 1998). Finally, while the study reports findings on the impact of 10th graders participation in a lived-in model to teacher preparation, it is difficult to disaggregate how much student growth is attributed to strong academic support offered by methods students versus other outside variables and factors.

\section{Implications}

This study provides insights into an under theorized, yet, significant area of inquiry for practitioners and researchers in teacher education-field and clinical experiences (Adler, 2008; Henning \& Yendol-Hoppey, 2004; Passe, 1994). This lived-in model to teacher preparation enhanced secondary students' attitudes and perceptions towards school while also demonstrating statistically significant gains in GPA. Those 10th graders not mentored by university method students were 2.5 times more likely to experience GPA declines from 1 st to 2 nd quarter than those 10th graders receiving the treatment. Through this lived-in model to teacher preparation, methods students and the methods professor, in concert with the 10th grade U.S. History teacher and English Language Art teacher, used an all hands on-deck approach to differentiate instruction and work to meet the individual learning needs of students. Under the direction of their methods professor and the 10th grade U.S. history teachers, methods students planned and implemented targeted interventions for those 10th graders underperforming and 
enrichment activities to extend the learning of 10th graders in each unit. This was possible in part due to the critical mass of well-prepared methods students that engaged in rapport building and in on-site instruction. While mentoring and teaching 10th grade students, methods students also benefited in their learning the importance of building rapport with high school students, the importance of flexibility and good planning, and of the overall unpredictable nature of schools.

The results of this study may be useful for teacher preparation programs looking to re-align their programs to the recently adopted CAEP Accreditation Standards (CAEP, 2013) which demand more embedded teacher preparation programs in PK-12 schools. We see this happening in two ways. First, moving away from ineffective field placements that only benefit teacher preparation programs that leach onto area schools and teachers for the sole purpose of helping teacher candidates clock field hours. Instead, under this model, teacher preparation programs are encouraged to create and sustain mutually beneficial partnerships with area schools that benefit not only the universities, but the schools and students they partner with. Partnerships that place PK-12 student success at the center while allowing for university method students to engage in meaningful opportunities to practice mentoring, tutoring, and teaching real students must be at the forefront of innovative and successful teacher preparation programs. As evident in the results of this study, sustained and repeated exposure of methods students- under the direct, on-site supervision of their methods professor-helped 10th graders academically and improved their attitudes and perceptions towards school. In fact, in anticipation of the holiday break, towards the end of the first semester, the control group demonstrated a somewhat common decline in academic achievement (i.e. GPA) whereas those 10th graders mentored by the university methods students seemed "inoculated" against this honeymoon period.

Second, we see this "lived-in" model to teacher preparation as a low-cost and highly effective way for teacher preparation programs to leverage their assets in assisting area schools in meeting the needs of their students-or what Foster (2008) calls making the invisible student visible. Such a model to teacher preparation, one that is committed to ensuring PK-12 student success while teacher candidates receive the experience and learning opportunities necessary to emerge as effective practitioners, allows for teacher preparation programs to become part of the solution instead of part of the problem.

\section{Conclusion}

The placement of university methods students in the field can tap into limited school resources and become burdensome for PK-12 educators (Zeichner, 2010). All too often in-service teachers and school administrator are left with a bad taste in their mouth when taking-on pre-service teaches, as they have to sacrifice precious time and resources that often go uncompensated, rewarded, or appre- 
ciated. New models that support and strengthen PK-12 partnerships with teacher preparation programs are needed (CAEP, 2013; U.S. Department of Education, 2011; Valencia, Martin, Place \& Grossman, 2009; Darling-Hammond, 2010). Field placements and PK-12 partnerships are vital to teacher preparation and methods yet this area of inquiry is significantly under explored (Adler, 2008; Henning \& Yendol-Hoppey, 2004; Passe, 1994). In this manuscript, we detailed and described the benefits of a lived-in model to teacher preparation. This approach embeds university method coursework and its adjoining field experience in an actual classroom for a sustained period of time whereby university faculty works with teacher candidates on-site to plan, assess, implement, and reflect on the quality of instruction. Moreover, all parties (methods professor, school teacher, pre-service candidate) prioritize and put at the center PK-12 student learning.

This study finds that our lived-in model to teacher preparation advanced the socio-emotional health and academic performance of the secondary students we mentored and taught. 10th graders we worked with demonstrated statistically significant gains when compared against the group not receiving this treatment in the areas of Academic Press, Adult Support, Positive Peer Relationships, and Sense of Safety. Since there was close to a 1:1 pairing of 10th graders to methods students, we were able to individualize instruction and build a supportive, caring, and differentiated learning environment. Furthermore, because of the strong relationship and rapport created between university methods students and secondary students, those 10th graders we mentored were 2.5 times more likely to earn higher GPAs than those not receiving the treatment in the second quarter. In particular, 10th graders being mentored by the methods students maintained a consistent average GPA throughout the semester, while those high school students in the control group demonstrated an average GPA decline.

Future research is necessary in this underexplored area of study. In particular, we are interested in whether prolonged exposure to university methods students' mentorship would lead 10th graders to meeting more of the nine socio emotional factors, and/or to greater statistically significant gaps between the treatment and control groups. Additional research is also needed to better understand the ways in which methods students' participation in a lived-in model to teacher preparation influences their perceptions, understandings, skills, and readiness. The field could benefit greatly from more practitioner-based accounts of successful ways teacher preparation programs have organized lived-in models to bolster teacher preparation, yet, also bolster PK-12 student performance. These accounts should highlight the perspectives of in-service teachers, university methods professors, and PK-12 students.

This research study finds that a lived-in model to university methods field partnerships, that prioritizes and puts at its center PK-12 student learning, can offer PK-12 students an individualized, supporting, welcoming, and caring learning environment-all important factors in bolstering students' academic 
performances. While high school teachers benefit from the additional support offered by university students and their professor, university methods faculty and their students benefit from the opportunity to plan, implement, and reflect on actual experiences with students in real classrooms while teaching. Such mutually beneficial models can go a long way in making teacher preparation programs a part of the solution.

\section{Conflicts of Interest}

The authors declare no conflicts of interest regarding the publication of this paper.

\section{References}

Adler, S. (2008). The Education of Social Studies Teachers. In L. S. Levstik, \& C. A. Tyson (Eds.), Handbook of Research in Social Studies Education (pp. 329-351). New York: Routledge.

Austin, E. J., Deary, I. J., Gibson, G. J., McGregor, M. J., \& Dent, J. B. (1998). Individual Response Spread in Self-Report Scales: Personality Correlations and Consequences. Personality and Individual Differences, 24, 421-438. https://doi.org/10.1016/S0191-8869(97)00175-X

Ball, D., \& Cohen, D. (1999). Developing Practice, Developing Practitioners: Toward a Practice-Based Theory of Professional Education. In L. Darling-Hammond, \& G. Sykes (Eds.), Teaching as the Learning Profession: Handbook of Policy and Practice (pp. 3-32). San Francisco, CA: Jossey-Bass.

Blackwell, L. S., Trzesniewski, K. H., \& Sweck, C. S. (2007). Implicit Theories of Intelligence Predict Achievement Across an Adolescent Transition: A Longitudinal Study of an Intervention. Child Development, 78, 246-263.

https://doi.org/10.1111/j.1467-8624.2007.00995.x

Council for the Accreditation of Educator Preparation [CAEP] (2013). CAEP Standards for the Accreditation of Education Preparation. http://caepnet.files.wordpress.com/2013/09/final_board_approved1.pdf

Darling Hammond, L. (2010). The Flat World and Education: How America's Commitment to Equity Will Determine Our Future. New York: TC Press.

Dewey, J. (1904/1965). The Relation of Theory To Practice in Education. In M. Borrowman (Ed.), Teacher Education in America: A Documentary History (pp. 140-171). New York: Teachers College Press.

Doppen, F. H. (2007). The Influence of a Teacher Preparation Program on Preservice Social Studies Teachers' Beliefs: A Case Study. Journal of Social Studies Research, 31, 54-64.

Fairbrother, M., Nicole, M., Blackford, J., Nagarajan, V., \& McAllister, L. (2016). A New Model of Clinical Education to Increase Student Placement Availability: The Capacity Development Facilitator Model. Asia-Pacific Journal of Cooperative Education, 17, 45-69.

Foster, H., \& Nosol, M. C. (2008). America's Unseen Kids/Teaching English/Language arts in Today's Forgotten High Schools. New York: Heinemann.

Gay, G. (2000). Culturally Responsive Teaching: Theory, Research, and Practice. New York: Teachers College Press.

Giles, R. M., \& Moore, A. L. (2006). Back to the Future: Teacher Educators Return to the 
Classroom. Teachers College Record.

http://www.tcrecord.org/content.asp? contentid=12673.

Good, C., Aronson, J., \& Inzlicht, M. (2003). Improving Adolescents' Standardized Test Performance: An Intervention to Reduce the Effects of Stereotype Threat. Applied Developmental Psychology, 24, 645-662. https://doi.org/10.1016/j.appdev.2003.09.002

Guillen, L., \& Zeichner, K. (2018). A University-Community Partnership in Teacher Education from the Perspectives of Community-Based Teacher Educators. Journal of Teacher Education, 69, 140-153. https://doi.org/10.1177/0022487117751133

Henning, M. B., \& Yendol-Hoppey, D. (2004). Context in Methods Course Learning: Lessons for Partnership Work. Teaching Education, 15, 401-416. https://doi.org/10.1080/1047621042000304529

Hollins, E. R. (2015). Rethinking Field Experiences in Preservice Teacher Preparation: Meeting New Challenges for Accountability. New York: Routledge.

Kenyon, E. (2013). Negotiating the Field: Exploring the Impacts of Moving Teacher Education to the Field. St. Louis, MO: The College and University Faculty Assembly of the National Council for the Social Studies.

Kopkowkis, C. (2008). Why They Leave? NEA Today Magazine. http://www.nea.org/archive/12630.htm

Midgley, C., Maehr, M. L., Hruda, L. Z., Anderman, E., Anderman, L., Freeman, K. E., Gheen, M., Kaplan, K. A., Middleton, M. J., Nelson, J., Roeser, R., \& Urdan, T. (2000). Manual for Patterns of Adaptive Learning Strategies. http://www.umich.edu/ pals/PALS\%202000_V13Word97.pdf

National Council for the Accreditation of Teacher Education NCATE (2010). Transforming Teacher Education through Clinical Practice: A National Strategy to Prepare Effective Teachers. http://caepnet.org/ /media/Files/caep/accreditation-resources/blue-ribbon-panel.pdf

Osler, W. (1901). Books and Men. Dedication Address, Boston: Boston Medical Library.

Passe, J. (1994). Early Field Experience in Elementary and Secondary Social Studies Methods Courses. Social Studies, 55, 130-133. https://doi.org/10.1080/00377996.1994.9956291

Patterson, A. D., McGoech, D. M., \& Olsen, H. C. (1990). A Brief History of the Association of Teacher Educators (2nd ed.). Reston, VA: Association of Teacher Educators.

Sleeter, C. (2008). Equity, Democracy, and Neoliberal Assaults on Teacher Education. Teaching and Teacher Education, 24, 1947-1957. https://doi.org/10.1016/j.tate.2008.04.003

Toll, C. A., Nierstheimer, S. L., Lenski, S. D., \& Kolloff, P. S. (2004). Washing Our Students Clean: Internal Conflicts in Response to Preservice Teachers Beliefs and Practices. Journal of Teacher Education, 55, 164-176. https://doi.org/10.1177/0022487103261625

U.S. Department of Education (2011). Our Future, Our Teachers: The Obama Administration's Plan for Teacher Education Reform and Improvement. Washington DC: US Department of Education. http://www.ed.gov/sites/default/files/our-future-our-teachers.pdf

Valencia, S. W., Martin, S. D., Place, N. A., \& Grossman, P. (2009). Complex Interactions in Student Teaching: Lost Opportunities for Learning. Journal of Teacher Education, 60, 304-322. https://doi.org/10.1177/0022487109336543

Walton, G., \& Cohen, G. L. (2007). A Question of Belonging: Race, Social Fit, and Achievement. Journal of Personality and Social Psychology, 92, 82-96. 
https://doi.org/10.1037/0022-3514.92.1.82

Washburn-Moses, L. (2014). Campus Mentors: A New Clinical Practice Model for Teacher Education. School University Partnerships, 7, 108-112.

Yeager, D. S., \& Walton, G. M. (2011). Social-Psychological Interventions in Education: They're Not Magic. Review of Educational Research, 81, 267-301. https://doi.org/10.3102/0034654311405999

Zeichner, K. (2010). Rethinking Connections between Campus Courses and Field Experiences in College- and University-Based Teacher Education. Journal of Teacher Education, 61, 89-99. https://doi.org/10.1177/0022487109347671

Zeichner, K. (2012). The Turn Once Again toward Practice-Based Teacher Education. Journal of Teacher Education, 63, 376-382. https://doi.org/10.1177/0022487112445789

Zeichner, K., \& Bier, M. (2015). Opportunities and Pitfalls in the Turn toward Clinical Experience in U.S. Teacher Education. In E. R. Hollins (Ed.), Rethinking Field Experiences in Preservice Teacher Preparation: Meeting New Challenges for Accountability (pp. 20-46). New York: Routledge.

Zeichner, K., Bowman, M., Guillen, L., \& Napolitan, K. (2016). Engaging and Working in Solidarity with Local Communities in Preparing the Teachers of Their Children. Jour nal of Teacher Education, 67, 1-15. https://doi.org/10.1177/0022487116660623 


\section{Appendix}

Social emotional survey reliability analysis.

\begin{tabular}{|c|c|c|c|c|}
\hline Factor & $\begin{array}{l}\text { Number of } \\
\text { Items }\end{array}$ & Sample Items & $\begin{array}{l}\text { Reliability } \\
\text { (Chronbach } \\
\text { Alpha) }\end{array}$ & $\begin{array}{l}\text { Scale } \\
\text { Mean } \\
\text { (SD) }\end{array}$ \\
\hline Academic Press & 4 & $\begin{array}{l}\text { The adults in this school press me to } \\
\text { do my very best work; Adults in this } \\
\text { school push me to be my best }\end{array}$ & 0.822 & $\begin{array}{c}4.72 \\
(1.25)\end{array}$ \\
\hline $\begin{array}{l}\text { Academic } \\
\text { Support }\end{array}$ & 4 & $\begin{array}{l}\text { The adults in this school give me the } \\
\text { help I need to be successful in school; } \\
\text { Adults in this school care about how } \\
\text { I'm feeling }\end{array}$ & 0.864 & $\begin{array}{c}4.33 \\
(1.29)\end{array}$ \\
\hline $\begin{array}{c}\text { Peer } \\
\text { Connections }\end{array}$ & 4 & $\begin{array}{l}\text { There are students in this school who } \\
\text { really understand me; I have good } \\
\text { friends at this school }\end{array}$ & 0.810 & $\begin{array}{l}4.73 \\
(1.4)\end{array}$ \\
\hline Sense of Safety & 4 & $\begin{array}{l}\text { I know I am safe when I am at school; } \\
\text { School is a place where I can relax and } \\
\text { be myself }\end{array}$ & 0.831 & $\begin{array}{c}4.08 \\
(1.44)\end{array}$ \\
\hline $\begin{array}{c}\text { Mastery } \\
\text { Orientation }\end{array}$ & 4 & $\begin{array}{l}\text { I really want to understand what I am } \\
\text { learning in school, not just memorize } \\
\text { it; One of my goals is to learn as much } \\
\text { as I can this year }\end{array}$ & 0.831 & $\begin{array}{c}4.9 \\
(1.18)\end{array}$ \\
\hline Self-Efficacy & 4 & $\begin{array}{l}\text { I know I can do well in school if I } \\
\text { work at it; I can learn almost anything } \\
\text { in school if I work at it }\end{array}$ & 0.837 & $\begin{array}{c}4.85 \\
(1.24)\end{array}$ \\
\hline $\begin{array}{l}\text { College-going } \\
\text { Identity }\end{array}$ & 4 & $\begin{array}{l}\text { I plan to go to college or some kind of } \\
\text { advanced training after high school; I } \\
\text { expect to earn a college degree after } \\
\text { my high school diploma }\end{array}$ & 0.912 & $\begin{array}{c}5.17 \\
(1.37)\end{array}$ \\
\hline $\begin{array}{l}\text { Future Self } \\
\text { Identity }\end{array}$ & 4 & $\begin{array}{l}\text { I know what my interests are for the } \\
\text { future; I have a plan for what I want to } \\
\text { do in the future }\end{array}$ & 0.682 & $\begin{array}{c}4.94 \\
(1.27)\end{array}$ \\
\hline $\begin{array}{l}\text { Perceived Value } \\
\text { of School }\end{array}$ & 4 & $\begin{array}{l}\text { My chances of future success will } \\
\text { improve if I do well in school; Doing } \\
\text { well in school will help me have the } \\
\text { kind of life I want later }\end{array}$ & 0.869 & $\begin{array}{c}5.17 \\
(1.18)\end{array}$ \\
\hline
\end{tabular}

${ }^{*}$ All items scored on a Likert-type scale $(1=$ not at all true for me; 6 = very true for me). 